\section{A Symposium organized by the Council for International Organizations of Medical Sciences}

Edited under the direction of R. E. Tunbridge by Madeline Keech, J. F. Delafresnaye and G. C. Wood. Pp. xii +37 I, illustrated. Oxford: Blackwell Scientific Publications. I957. 42s.

This book consists of 26 papers with edited versions of the ensuing discussions, presented at a symposium on connective tissue under the chairmanship of Professor R. E. Tunbridge. Most of the papers deal with the biochemistry of connective tissue, although some are concerned with the morphological approach. It is obvious that great progress has been made towards an understanding of this important and somewhat neglected part of the human organism, and this book is filled with up-to-date basic data so essential to all who are interested in disorders of connective tissue. The only criticism, and it is a very minor one, is that some of the illustrations are very small and in one instance as many as 12 are bunched together on one plate.

\section{FRAZER'S ANATOMY OF THE HUMAN SKELETON}

Edited by A. S. Breathnach, M.D., M.Sc. Fifth edition. Pp. viii +247 , with 197 illustrations. London: J. \&. A. Churchill, Ltd. 1958. $£ 2$ ros. od.

British anatomists have produced at least three outstanding textbooks of human osteology. Of these, alas, two have passed into a limbo, large and broad, and are, regrettably, barely known at the present time. These are G. M. Humphry's 'Treatise on the Human Skelton (including Joints),' which was published just roo years ago, and the earlier ' Outlines of Human Osteology' by by $\mathrm{F}$. O. Ward, the second edition of which was produced in the same year as Humphry's book. Ward was not a professional anatomist, nor even medically qualified; his book, however, must be ranked as one of the classics on the subject.

Frazer's book ranks with these works, and indeed he probably derived much inspiration from them. His book is a classic, and, deservedly, has been the only outstanding textbook of Human Osteology in use for a period of well nigh 50 years. Its unique approach, accuracy and attractive figures have undoubtedly contributed much to its success.
These works of Humphry, Ward and Frazer are characterized by the individuality of their style and approach to the subject. They do not lend themselves easily to revision and rewriting, for, with such treatment, they are likely to lose much of their character and value. They are the personal records of the personal observations of these men and bear the stamp of originality. For this reason one is grateful to the editor of the fifth edition of Frazer's book for his conservatism. The bulk of the book is unchanged from previous editions. The introduction has been largely rewritten and some parts have been brought up to date. For the first time radiographs (called X-rays by the editor) are introduced without greatly enhancing the value of the book. Strangely, no radiograph of the skull is included.

A few references, presumably intended to be of a critical nature, have been added at the end of each chapter. These do not include a reference to R. Walmsley's Struthers' lecture on the inter vertebral disc, the reviews on joints by Bauer Ropes and Waine, the reviews by Gardner and Brantigan and Voschel's works on the knee. It is surprising also that there is no reference to Sneath's work on the insertion of the biceps femoris. Pride of place is given to MacConaill as describing the predominantly fibrous nature of articular cartilage. It is over 200 years since William Hunter wrote of this: "Then we may compare the texture of cartilage to the pile of velvet, its fibres rising from the bone as the silky threads that rise from the woven cloth or basis.' Though their methods of investigation were much more limited than ours, it is surprising how much the older anatomists have to teach us and how little escaped their notice.

The nomenclature of this edition of Frazer's book is a very mixed one. It contains a mixture of eponymous, Basle Nomina Anatomica, Birmingham Revision and Paris Nomina Anatomica terms. It would be impossible to standardize its terminology without redrawing and remaking the blocks for all the figures. This would be a tedious and expensive task and would add greatly to the cost of the book. Time will tell how important this may be. How many recently qualified men, or indeed how many of the younger anatomists, know what the process of Kerkring, Chassaigne's tubercle, Cooper's ligament or the canal of Verga are? Attention to the nomenclature used will become inevitable in time and may prove more important than references to Australopithecinae, Neanderthal man and Pithecanthropus erectus. 
These are relatively small criticisms and it is hoped that readers will not take them as a condemnation of the book. Frazer's Anatomy of the Human Skeleton remains an excellent treatise which can be wholeheartedly recommended to undergraduates, medical students, postgraduate students and anatomists alike. It gives a refreshing and stimulating approach to the subject of osteology, and indeed to anatomy as a whole, which is not found in any other textbook.

\section{PRACTICAL ALLERGY}

By M. Coleman Harris, M.D., F.A.C.P. and Norman Shore, M.D., M.S., F.A.C.P. Pp. xiii +47 I, with 25 illustrations. London: Butterworth \& Co. Ltd. I958. 52s. 6d.

This book sets out to provide practical information for physicians and general practitioners interested in treating allergic disorders, rather than for allergists.

The authors are careful to define what they mean by allergy, and describe the differences between the immediate and the delayed types of allergic reaction.

The book describes in detail the approach to allergic diagnosis, rightly stressing careful historytaking rather than skin tests. It goes on to describe the common allergies and their management. Detailed pollination season tables are only given for the United States, although brief ones for Britain are given.

The authors include 40-odd pages on miscellaneous diseases, including the collagenoses, in which they admit that the allergic origin is not yet fully proven. As in practice the management of these diseases is not anti-allergic they could have been omitted.

The book can be recommended as a readable and informative book on allergy for the non-allergist.

A.W.F.

\section{MODERN TRENDS IN PAEDIATRICS Second Series}

Edited by A. Holzel and J. P. M. Tizard. Pp. xxiii +372 with 46 illustrations. London: Butterworth \& Co. Ltd. I958. 70s.

This is the most important and stimulating large book in the field of paediatrics which has been published since the war. The majority of the contributors are young and each has succeeded admirably in fulfilling the two tasks set him by the editors: to survey a subject of growing importance and to speculate about possible future developments.

The chapters on genetics and child psychiatry are both fascinating and challenging. At the moment 46 per cent of the hospital beds in this country are occupied by mental patients-either mentally retarded or disordered. The discovery of genetically determined biochemical abnormalities is already offering prospects of amelioration of one or two types of mental defect; but, as yet, attempts at eugenic control are hardly justifiable. On the psychiatric side it is at long last becoming generally recognized that the only time to prevent people growing up with sexual deviations or prevent adults getting psychotic illnesses is by detecting and treating the abnormalities in the early stages, i.e. in the first few years of life. British paediatricians have, on the whole, been slow to realise this and it is welcome to see such support to this view here. Although the need for personal psychoanalysis of the doctor is overstressed, there can be no belittling of the important lessions which psychoanalysis can teach the paediatrician.

The chapter on congenital heart disease is wisely selective and shows that any further significant reduction in mortality means diagnosis and treatment in the first year of life.

The sections on corticosteroids and on mineral metabolism both distil the essentials from a literature which has become uncomfortably vast.

The only chapters which do not quite reach the high standards of the rest of the book are those on neonatal pathology and allergy. In their different spheres, each fails to pin-point the real problems.

Three interesting chapters on the work of a provincial paediatrician in the U.S.A., U.S.S.R., and U.K. reflect the different national approaches to medicine.

Other good contributions are on vital statistics, anoxia, neonatal surgery, haematology, virus diseases, malignant diseases, convulsions, neurosurgery, chromatography, radiocative isotopes and physical growth.

\section{TEXTBOOK OF BRITISH SURGERY}

Edited by Sir Henry Souttar, C.B.E., D.M., F.R.C.S., and J. C. Goligher, Ch.M., F.R.C.S. Volume Three. Pp. viii + 6rg, with 206 illustrations. I958. I05s. London: William Heinemann Ltd.

Publication of the third volume completes this fine work. In this volume pride of place has been given to genito-urinary surgery and peripheral vascular diseases. Amongst the other subjects are the surgery of the adrenal and parathyroid glands; radiology and radiotherapy, and fluids and electrolytes. The high standard of the previous two volumes has been fully maintained. This work is strongly recommended.

\section{THE TISSUES OF THE BODY}

\section{An Introduction to the Study of Anatomy}

By W. E. Le Gros Clark, F.R.S. Fourth edition.

Pp. xi +415, I 27 figures. I 958 . 40s. London:

The Clarendon Press.

Since its first appearance in $1939^{\text {' The Tissues of }}$ the Body' has become firmly established as one of the most stimulating text-books which can be put into the hands of the medical student. As an introduction to the study of anatomy it was at that time revolutionary, making a clean break with the 